\title{
Gyermekvédelmi szakellátásban élő tanulók iskolai esélyei
}

\author{
Dobokai Róbert Lászlóné Simon Dóra*
}

Tanulmányom a gyermekvédelmi szakellátásba vett általános iskolai tanulók iskolai esélyeivel foglalkozik. A gyermekvédelmi szakellátásban felnövő, illetve abban a rendszerben élő gyermekek és fiatalok felnötté válásuk során a társadalom alsó rétegét szélesitik. A társadalmi kirekesztettség, a minőségi kapcsolatok, a gazdasági, kulturális, szociális tőke hiánya miatt bizonytalan a társadalmi integrációjuk is. Az iskolában megszerzett tudás a társadalmi mobilitásuk záloga lehet. Az oktatás-nevelés intézményrendszere, valamint a benne tevékenykedő pedagógusok megfelelő elköteleződéssel és felkészültséggel esélyt és segitséget is adhatnak e tudás megszerzésére, a magasabb iskolai végzettség megszerzésére. Mindezek mentén túztem ki célul annak vizsgálatát, hogy azok a pedagógusok, akik a gyermekvéde lemi szakellátásban élő tanulók általános iskolai oktató-nevelő tevékenységét végzik, milyen tapasztalatokkal rendelkeznek, milyen iskolai nehézségeket látnak, milyen konkrét problémákkal küzdenek. Kutatásom stratégiája mind az induktiv, mind a deduktiv stratégia jellemzőit magán viseli, vizsgálódásom során a dokumentumelemzés, a szóbeli és az írásbeli kikérdezés módszerét egyaránt felhasználtam. Kutatásom terepe Bács-Kiskun megye volt, de azt feltétele zem, hogy más megyék is hasonló képet mutatnak a mai Magyarországon. Vizsgálati eredményeim a gyermekvéde lemben felnövekvő tanulók iskolai esélyteremtésében és iskolai eredményességében tematizálható problémákat mutatnak. A pedagógusok nem felkészültek a gyermekvédelemben élő tanulókkal való egyéni bánásmódra, valamint e tanulók iskolai eredményességének növelésére. A pedagógusok nem vesznek részt olyan továbbképzésen, mely fókuszál a gyermekvédelemben felnövő tanulók sajátosságaira, vagy segíti az érdekükben sikeresen alkalmazható pedagógiai módszerek elsajátitását. Láthatóvá vált az is, hogy az általános pedagógusképzés során a kötelező kurzusok tananyaga csak elvétve tér ki külön a gyermekvédelemben élö tanulókkal kapcsolatos tartalmi elemekre.

Kulcsszavak: gyermekvédelem, esélyteremtés, pedagógusok

\section{Bevezetés}

Kutatásom a gyermekvédelem otthont nyújtó ellátási formájában élő ${ }^{1}$ általános iskolások esélyeivel foglalkozik. Azt vizsgálom, hogy e tanulók érdekében végzett iskolai pedagógiai munka milyen nehézségekbe ütközik, milyen problémákkal küzdenek a pedagógusok, illetve hogyan segítik az iskolai esélyek növelését. Megelőző kutatások azt mutatták, hogy a gyermekvédelmi gondoskodásban felnövő gyermekek és fiatalok felnőtté válásuk során döntően a társadalom alsó rétegét szélesítik. A társadalmi kirekesztettség, valamint a minőségi kap csolatok és a gazdasági, kulturális, szociális tőke hiánya miatt bizonytalan a társadalmi integrációjuk is (Varga, 2012). Számos nemzetközi kutatás számol be a gyermekkori hátrányaik sikertelen leküzdéséről is (Rácz, 2012).

általános iskolai tanító, Dávodi Forrás Általános Iskola Csátaljai Tagintézménye, e-mail: simondora5@freemail.hu

1. A gyermekvédelmi törvényben meghatározottak szerint a gyermekvédelem szakellátó rendszere otthont nyújtó ellátási formát tart fenn azon gyermekek számára, akik valamilyen ok miatt családjukban nem kaphatják meg egészséges fejlődésükhöz a megfelelő gondoskodást. Az idősoros adatok szerint az elmúlt 10 évben 18000-20000 körül mozgott országos szinten a gyermekvédelmi gondoskodás otthont nyújtó ellátási formájában élők száma, akik több mint fele iskoláskorú. (Forrás: https:// www.ksh.hu/docs/hun/xstadat/xstadat_eves/i_fsg001.html Letöltés ideje: 2019. 06. 18.) 
Ugyanakkor az iskolában megszerzett tudás ebből a helyzetből való kitörés záloga lehet. Az oktatás-nevelés intézményrendszere, illetve a benne tevékenykedő pedagógusok kulcsszerepe vitathatatlan, hiszen ők nyújthatnak esélyt a különböző tőkehiányok kompenzálására, az ő támogatásuk elengedhetetlen a magasabb iskolázottság megszerzésében. Feltehető azonban a kérdés, hogy megkapják-e az iskolákban a gyermekvédelemben élők az esélykiegyenlítő, méltányos támogatást, illetve tudnak-e ezzel élni. Ugyanakkor kérdés az is, hogy a pedagógusok képesek-e megadni a gyermekvédelmi szakellátásban élő tanulóiknak azt a segítséget, mely biztosíthatja számukra az esélyt a társadalmi mobilitásra.

A fenti kérdésekre keresem a választ, elsóként olyan szakirodalmi forrásokban, melyek a gyermekvédelmi szakellátásban élő tanulók és családi hátterük, szocializációjuk jellemzőit vizsgálják, az iskolai esélyeket fejtegetik, a megváltozott iskolai szemlélet fontosságára hívják fel a figyelmet, illetve jó gyakorlatokat is bemutatnak. E források empirikus kutatásom elméleti, értelmezési alapjait jelentik, valamint a vizsgálódásomhoz használt kérdőív összeállításához is segítséget nyújtottak.

A rövid szakirodalmi áttekintést követően a Bács-Kiskun megye általános iskoláiban végezett kutatásomról számolok be. Igyekeztem feltárni, hogy milyen problémákkal küzdenek, milyen szemlélettel rendelkeznek a megkérdezett pedagógusok a gyermekvédelemben élő tanulókkal folytatott munka kapcsán, továbbá, hogy kapnak-e megfelelő támogatást ehhez a munkához. Egyrészt a kérdőíves lekérdezés részeként, másrészt dokumentumelemzéssel jártam utána, hogy a pedagógusképző intézmények kurzusanyaga kitér-e a gyermekvédelmi ismeretek oktatására.

Vizsgálódásaim megmutatják, hogy a gyermekvédelmi szakellátásban élő tanulók szociokulturális jellemzői a pedagógiai munka során milyen nehézségeket generálnak, mennyire jellemző a megváltozott iskolai szemlélet, a pedagógusok igényelnek-e szakmai segítséget, valamint jelen van-e a partnerek közötti együttmüködés. Reményeim szerint eredményeim olyan problémákra és megoldásokra világítanak rá, melyek figyelembe vétele sikeresebbé teheti a gyermekvédelmi szakellátásban felnövekvő tanulók iskolázási esélyeit.

\section{Esélyteremtés}

Az alábbiakban az esély iskolai dimenzióival összefüggésben fókuszálok a gyermekvédelmi szakellátásba helyezett tanulók sajátosságaira, szociokulturális jellemzőkre. Célom, hogy feltárjam, milyen iskolai esélyei vannak ezeknek a tanulóknak és vajon tudnak-e élni ezekkel. Kiindulópontként tekintek arra a megállapításra, hogy az iskola transzmissziós szereppel bír az egyén és a társadalom között, mivel az oktatás hosszú távú beruházásként mind az egyén életútját, személyes esélyeit, mind a társadalom sikerességét, integrációs esélyeit befolyásolja (Bárdossy, 2000).

Az esélyegyenlőség elve társadalmi és iskolai szinten az egyenlő bánásmód kívánalmát fogalmazza meg, és hangsúlyozza azokat a méltányos támogatásokat, mely az egyenlőtlen helyzetben lévők kiemelt támogatását jelentik hátrányaik kompenzálása érdekében (Varga, 2015a). Személyes szinten vizsgálva az esély azt jelenti, hogy valaki képes arra, hogy tegyen valamit, vagy rendelkezzen valamivel. Az esély az egyén oldaláról feltételezi a hozzáférhetőséget és egyúttal aktivitást is feltételez. A valódi esélyteremtéshez szükséges ismerni a különböző lehetőségeket, mely az információkhoz való hozzáférés megteremtését jelenti. Az esélyteremtés másik oldala a helyzetfelismerés és az önismeret, azaz fontos, hogy az egyén tudatosan kezelje „versenyképességeit”, hogy megfelelőek legyenek a lehetőségekhez való viszonyulásai (Mihály, 1999).

Ha az esélyegyenlőség kérdéskörét a gyermekvédelemben felnövő tanulókra vonatkoztatjuk, akkor talán nem alaptalanul arra a következtetésre jutunk, hogy az ő esélyeik egyértelmúen rosszabbak, hiszen e gyerme- 
kek összetett problémákkal küzdenek. A pszichológiai sajátosságok - melyek jellemzően a hospitalizációból, a szeparációs szorongásból adódnak - már eleve sérült személyiségfejlődésre utalnak (Varga, 2012). Ezek a ta nulók később olyan problémákkal is küzdhetnek, mint a szeretethiány, a biztonságérzés hiánya, a nem megfe lelő nyelvi kultúra, agresszivitás, passzivitás, negatív énkép, önbizalom hiánya (Veressné, 2002, id. Varga, 2012). Fülöpné szerint e gyermekek mindegyike esetében szükséges lenne az egyéni fejlesztés, hiszen értelmileg, érzelmileg sérültek (Fülöpné, 2003).

Ezen gyermekek szocializációja sajátságos, mivel a primer szegmens - egymással sokszor ellentmondásban lévő - kettőssége folyamatosan jelen van. A gyermekvédelem által gondozott gyermekek döntő többsége életének több szakaszában is vérszerinti családjával él, illetve szoros a kapcsolattartása még akkor is, ha már nevelőszülő vagy gyermekotthon neveli. A családból való kiemelés oka legtöbbször éppen az, hogy nem megfelelő a szociokulturális háttér, hiányzik az anyagi biztonság, a gondoskodás, megélik a családban a devianciák - al kohol-, drogfüggőség, bántalmazás - legkülönbözőbb formáit, melyek veszélyeztetik az egészséges személyiségfejlődést. Jellemzően a család gazdasági, kulturális és társadalmi tőkefelhalmozása sem sikeres (Bourdieu, 1978), a gyermekvédelemben élők döntő többségét a társadalom alsó tíz százalékába tartozó családokból veszik gondozásba. A gyermekvédelem otthont nyújtó ellátórendszere egy olyan esélyteremtő ellátásként kell, hogy múködjön, mely ellensúlyozni tudja a családi, sokszor traumatizált élethelyzetet úgy, hogy közben biztosítja a gyermeknek a családhoz való jogát a kapcsolattartás, visszagondozás tevékenységeivel. Mindezek összessége eredményezi, hogy a család és gyermekvédelem kettős hatása mentén gyakran deviáns magatartás, tanulási nehézségek jellemzik az ilyen helyzetben nevelkedő tanulókat, mely élethelyzet negatívan befolyásolja a tanulási motívumaikat is. Éppen ezért kiemelkedő fontosságú, hogy a pedagógusok ismerjék a gyermekvédelemben élők sajátosságait, és minden lehetséges eszközzel segítsék e tanulókat iskolai pályafutásuk során, növeljék iskolai, társadalmi esélyeiket.

A gyermekvédelem otthont nyújtó ellátásában élő tanulók esetében kiemelten fontos, hogy képesek legye nek maguk is aktív szerepet vállalni hátránykompenzálásukban. Elsőként azonban a gyermekvédelmi és az oktatási rendszer esélyteremtő cselekvéseire van szükség, mely az esélyekért való versenyfutásban csak a starthelyzet egyenlőségét teremti meg (Mihály, 1999). Iskolai vonatkoztatási keretben tehát arra kell gondolnunk, hogy egyenlő feltételeket kell biztosítani minden iskolás tanulónak, azonban ez csak a startvonal, mely önmagában nem elegendő a sikerességhez. Az információkhoz, javakhoz egyenlőtlen mértékben hozzáférő, az esélyekkel élni nem tudó diákokat méltányos támogatásokkal kompenzálni, „kárpótolni” kell, mert csak így érhető el a valódi esélyegyenlőség (Varga, 2015). Ehhez egyre szélesebb összefogásra, szakmai, pedagógiai kompetenciafejlesztésre, koordinált együttmúködésre van szükség az állam, az intézményfenntartók, a szülók, a diákközösségek, valamint az iskolák részéről is (Bárdossy, 2000). A gyermekvédelemben felnövők tekintetében pedig az iskola és az otthont nyújtó ellátás szereplői között elengedhetetlen a „közös gondoskodás” felelősségvállalása, melynek része az erre való felkészültség is (Varga, 2012).

\section{Megváltozott iskolai szemlélet}

Az alábbiakban röviden áttekintem a megváltozott iskolai szemlélet mibenlétét és fontosságát, hiszen a gyermekvédelmi szakellátásban élók alacsony gazdasági, szociális és kulturális tőkefelhalmozásának növelése öszszetett probléma, mely a hagyományos követelő - büntető - jutalmazó szemlélettel szinte kivitelezhetetlen.

Napjaink égető problémája a hátrányos, illetve halmozottan hátrányos helyzetú, mélyszegénységben élő tanulók - szinte determinált - iskolai esélye. Különösen fontossá válik ez a lemorzsolódás megelőzése mint okta- 
táspolitikai fókusszal összefüggésben (Fehérvári, 2015a). Több vizsgálat is rávilágít azokra a tényekre, amelyek általában jellemzik a társadalmi hátránnyal küzdő tanulókat és családi helyzetüket, úgymint a térségi hátrány, a kistelepülési lét, a szülók alacsony iskolai végzettsége, gyenge munkaerő-piaci pozíciója, tanulással kapcsolatos motiválatlansága, inaktív státusa és a szegénység. Az iskolai kudarcok lehetséges okai között szerepel az óvodáztatás megfelelő mértékének elmaradása, a szegregáció különböző formái, a megoldatlan konfliktus a csa lád és az iskola között, valamint a társadalmi elöítéletek (Mayer, 2006; Fehérvári, 2015b; Kertesi \& Kézdi, 2012; Híves, 2015; Varga, 2015a).

A gyermekvédelmi szakellátásban élők jellemzője lehet a magatartászavar, az érzelmi sérülés, az állandósult kudarcélmény. Ők az iskolában gyakorta megbélyegzettek, kirekesztettek (Platthy, 1994). Nagyon fontos, hogy az iskola ezen jellemzőkre megfelelően reagáljon, és esélyt nyújtson azoknak a gyermekeknek is, akik testi, lelki, tanulási nehézségekkel, vagy egyéb lemaradással küzdenek.

Bárdossy úgy tekint az iskolára, mint lehetséges integrációs, illetve reintegrációs kulcsintézményre, ehhez azonban az szükséges, hogy pedagógusai ismerjék fel és tudják kezelni az egyének és csoportok különbözőségeit. Megállapítja, hogy az oktatás kohéziós erővé válhat, ha tudomásul veszi az egyének és csoportok sokféleségét, és elkerüli, hogy ő maga is kirekesztő tényező legyen. Kiemeli, hogy bár az iskola sok esetben a társadalmi kirekesztés helyszíne, ugyanakkor felértékelődött, mint az integráció és reintegráció kulcsintézménye (Bárdossy, 2006). Ahhoz tehát, hogy a perifériára szorult gyermekek is megfelelő módon fejlódhessenek, tanulhassanak, és ne legyenek potenciális iskolaelhagyók, megváltozott iskolai szemléletre, méltányosságra, inkluzív iskolára van szükség. A gyermekvédelmi szakellátásban élő tanulók jövője szempontjából létkérdés annak megteremtése, hogy iskolai sikereket érjenek el, jó eredményeket produkáljanak (Hart \& Williams, 2014).

A befogadó iskolai kultúra azt jelenti, hogy mindenkit olyannak fogadnak el amilyen, hiszen léteznek külön böző egyének, kultúrák, életmódok egy időben és egy helyen. Ugyanakkor nem beolvasztani akar, hanem felismerni a különbözőségeket, és ezekhez a különbözőségekhez alkalmazkodik a tananyagtartalom, a tanítási módszer, a követelmény és az értékelés is. A pedagógus épít a különböző identitású diákok tapasztalataira, képességeire, tudására. Az iskolai inkluzív szemlélet ezért figyelembe veszi a gyermekvédelemben élők összetett élethelyzetét, sajátosságait, az egyén felé fordul, figyelme középpontjába helyezi az individuum szükségleteit. A professzionális pedagógus képes ezen tanulók szociális tőkéjét erősíteni, ebben komoly szerepet szán az alkalmazott módszereknek (Varga, 2008, 2015b). Ugyanakkor nem elég az inkluzív szemlélet meghonosítása, szükséges a fokozatos gyakorlati fejlesztése is (Kalocsainé \& Varga, 2005).

Réthyné a legfontosabb módszerek között említi a kreativitásra, a kooperativitásra és a reformpedagógiákra támaszkodó stratégiákat. Ezek hozzásegítenek a differenciált oktatáshoz, az individualizációhoz. Fontos a kirekesztés prevenciója, a pozitív teljesítményelvárás, az elfogadó légkör, az együttműködés, a tevékenykedtető oktatási formák, a gyakorlatra orientáltság, a motiválás, a komplex értékelési formák. Pozitív gyakorlat az egyéni fejlesztési terv, a differenciált tanterv és követelmények (Réthyné, 1988).

A megváltozott iskolai szemlélet a pedagógusok megváltozott szemléletéből ered. Szükséges, hogy a professzionális pedagógusok elkötelezettek legyenek az új tanítási és tanulási stratégiák tekintetében, és egyéni tanulási útvonalat jelöljenek ki. E tanulók esetében hatékony a frontális oktatás visszaszorítása, és az egyéni, inter-kommunikációra épülő - „face to face” típusú - óravezetés, valamint a tanulási-tanítási folyamat iskolai falakon is túllépő szervezése. Fontos, hogy a pedagógus a tanuló személyiségét és a vele kapcsolatos problémákat állítsa a középpontba. Lételem a tanulók ráhangolása, előzetes tudásának feltárása, és az erre történő építkezés, a hátránykompenzálás, a tanulók aktív szerepvállalása, az interaktív tanítási órák, a kommunikáció, a 
differenciálás, valamint az alacsony osztálylétszám. Jó, ha mindez vonzó iskolai környezetben valósul meg (Mayer, 2006).

\section{Szektorközi együttmüködés}

A megváltozott iskolai szemlélet mellett igen hangsúlyos a különböző szektorok - oktatás, egészségügy, gyermekvédelem - szakmai munkájának összehangolása. Fontos a folyamatos, rendszeres kapcsolattartás, tapasztalatcsere az oktatásban tevékenykedő többi segítő szakemberrel - pszichológussal, fejlesztő pedagógussal, kollégákkal, osztályfőnökkel -, külső partnerekkel, mint az otthont nyújtó ellátást biztosítókkal, gyermekvédel mi szakdolgozókkal, esetleg egészségügyi szakemberekkel.

A napi együttműködés mellett döntő a gyermekvédelmi szakellátásban élők iskolai támogatására társadalmi feladatként tekinteni, mely igényli a különböző szakpolitikák - szociálpolitika, oktatáspolitika, egészségügy összehangolását, szektorközi együttműködését.

A gyermekvédelemre irányuló kutatások azt mutatták, hogy nincs rendszerszerū együttmúködés a szociális és az oktatási szektor között, az oktatási szféra nem kapcsolódik be oly mértékben a gyermekekkel kapcsolatos iskolai problémák megoldásába, hogy az eredményesebb legyen (Varga, 2012, 2015b). A szektorközi együttmúködés a mindennapok során azt igényelné, hogy az egyes területek dolgozói - pedagógusok, pszichológusok, fejlesztő pedagógusok, nevelőszülők, nevelőtanárok, gyámok, nevelőszülői tanácsadók - között folyamatos és naprakész legyen az információcsere, a kapcsolattartás, a tapasztalatok megosztása, a segítségnyújtás, az együttmúködés. Az egyes szakterületek dolgozói által feltárt problémák közös fórumokon, egyeztetéseken történő felvázolása szektorközi továbbképzések témája lehetne. Az iskolák cselekvési tervei fókuszálhatnak a gyermekvédelemre, illetve a fent említett együttmüködés fokozására is.

\section{Vizsgálati célok és keretek}

A kutatás Bács-Kiskun megye általános iskoláiban valósult meg 2014-2018 között, a gyermekvédelem és az iskolázottság összefüggéseinek feltárását célozva meg. A két stratégiai terület - gyermekvédelem és oktatás hangsúlyát indokolja, hogy ebben a témában kevés a feltárt, feldolgozott kutatási terület, valamint a gyermek védelem alatt áló tanulók iskolai eredményessége kívánnivalót hagy maga után (Varga, 2012).

Jelen vizsgálat az általános iskolás, gyermekvédelmi szakellátásban élő tanulókra fókuszált, rájuk vonatkoztatva gyüjtött információkat. Az iskolafok kiválasztásában szerepet játszott, hogy az általános iskola az a közoktatási szint, mely meghatározza a továbbtanulási esélyeket. Továbbá ez az az iskolafok, ahol a legnagyobb arányban találhatók a gyermekvédelemben élő tanulók.

A vizsgálat célkitűzése volt, hogy összegyüjtésre kerüljenek azok a problémák, amelyekkel a pedagógusok küzdenek a gyermekvédelmi szakellátásban élő tanulókkal folytatott pedagógiai munka során. Szintén cél volt a megoldások felkutatása is. Mindezekkel összefüggésben górcső alá került a hazai tanítóképző főiskolák és tanárképző intézmények tanterve. A dokumentumelemzés a bennük szereplő gyermekvédelmi kurzusokat vizsgálta, melyek megalapozhatják a pedagógusok hozzáállását, szakértelmét ezen tanulókhoz kötődően. A megfelelő szakmai tudás, a pozitív attitǔd ugyanis elengedhetetlen feltétele a gyermekvédelmi szakellátásban élő ta nulók iskolai sikerességének. A vizsgálat részeként interjúk készültek, hogy képet kapjunk a gyermekvédelmi szakemberek azon véleményéről is, melyek az együttműködésre, iskolával kapcsolatos nehézségekre, valamint az elégedettségre vonatkoznak. Mindez azt célozta, hogy Bács-Kiskun megyében a gyermekvédelmi szakellá- 
tásban élő tanulók és pedagógusok iskolai problémáit feltérképezzem, megtaláljam és összegyújtsem azokat a lehetőségeket, amelyek sikeresebb iskolai előmenetelhez juttathatják e tanulókat.

A kutatás alapsokasága azon Bács-Kiskun megyében oktató-nevelő tevékenységet végző általános iskolai pedagógusok, akik gyermekvédelmi szakellátásba vett tanulókat is tanítanak. A Bács-Kiskun megyei tankerületi vezetők segítségével kiküldésre került az online pedagógus kérdőív, melyre 226 értékelhető válasz érkezett. Ez a megyében lévő általános iskolai pedagógusok 5\%-a. ${ }^{2}$ A választ adó tanárok, tanítók háromnegyede $(75,2 \%)$ legalább 20 éve pályán lévő, 41-60 év közötti életkorú, 87,6\%-uk nő. Legnagyobb részük kisvárosi és falusi, kis létszámú iskolában tanít.

A kérdőív zárt és nyitott kérdései 8 témakört érintettek, 28 fö- és 98 részletes kérdéssel. A fő kérdéskörök az alábbiak voltak:

- A pedagógusok tapasztalatai, problémái, szemléletmódja a gyermekvédelmi szakellátásban éló általános iskolás tanulókkal kapcsolatban.

- Az intézményi gyermekvédelmi felelősök munkája, illetve a gyermekvédelmi szektor dolgozóival való kapcsolattartás megléte.

- A pedagógusok végzettsége a gyermekvédelem területén.

- A tanárok, tanítók és a gyermekvédelmi szakemberek kapcsolattartásának minősége, mennyisége.

- A pedagógusok segítségnyújtási módszerei a gyermekvédelmi szakellátásban éló tanulók iskolai teljesítményének javítása érdekében.

- A gyermekvédelmi szakellátásba vett tanulókat segítő tényezők jó tanulmányi eredmény elérése esetén.

- A gyermekvédelmi szakellátásba vett tanulókat gátló tényezők gyenge tanulmányi eredmény elérése esetén.

- A pedagógusok munkájának önértékelése az e tanulókkal folytatott oktató-nevelő munkával kapcsolatosan.

A fenti témakörök mellett volt még néhány olyan területet, mely nem sorolható be egyik kérdéskörbe sem. Ezek a tanulók továbbtanulásával kapcsolatosak, valamint a tanárok, tanítók sikereire, kudarcaira összpontosítottak az oktató-nevelő munka során.

Az online lekérdezés kiegészítéseként a gyermekvédelmi szektorban dolgozók körében is zajlott vizsgálódás. Mélyinterjúk készültek (N:3) a gyermekvédelmi szektor szakdolgozóival, valamint fókuszcsoportos beszélgetések zajlottak nevelőszülókkel ( $\mathrm{N}: 8)$.

A pedagógus kérdőívet a Google rendszer on-line kérdőívkészítő szoftvere segítségével állítottuk össze. A feldolgozás számítógépes elemzéssel történt, mely segített összegezni, csoportosítani az adatokat. Az interjúk, fókuszcsoportos beszélgetések feldolgozásához tartalomelemzést alkalmaztunk.

2. A vizsgált időszak közepét (2016/2017-es tanév) alapul véve a vizsgált megyében dolgozó általános iskolai pedagógusok száma: 4128 fő. (Forrás: Köznevelési Statisztikai Évkönyv 2016/2017, Budapest, 2018. Emberi Erőforrások Minisztériuma. 81. oldal) 


\section{Eredmények - pedagógusok kérdőíves vizsgálata}

A gyermekvédelmi szakellátásban élő általános iskolai tanulókat tanító, kutatásba bekapcsolódó pedagógusok nagy része nehézségekkel küzd e tanulók oktatása, nevelése során. Leggyakoribbak a magatartási és tanulási motivációs problémák. A választ adó pedagógusok 81,9\%-a befogadó szemléletű, a szegregáció semmilyen formáját nem támogatja, bár egyes vélemények szerint nem elhanyagolható az a tény, hogy több figyelmet kapnának e tanulók szegregált oktatás során.

Külön gyermekvédelmi felelős a kollégák intézményében 55,3\%-ban van jelen, legtöbben heti 1-2 órában, illetve alkalomszerúen látják el tevékenységüket. A tanárok, tanítók az intézményi dokumentumaik gyermekvédelemmel kapcsolatos vonatkozó részeit inkább ismerik, azokat megfelelőnek tartják. Az iskoláknak speciális cselekvési terve a gyermekvédelmi szakellátásban élő tanulók iskolai eredményességének javítása céljából általában nincs, ahol van, ott sem deklaráltan e célcsoportra vonatkozik.

A válaszadó pedagógusok nagyobb része több mint húsz éve végzett első diplomája szerint, és a legtöbben azóta újabb diplomát szereztek. Sem az első képzés során, sem az új diploma adta képzés nem terjedt ki a gyermekvédelmi ismeretek oktatására a választ adó pedagógusok nagy része esetében. Ezt a képzést azonban fontosnak tartanák.

Szakmai segítséget a gyermekvédelmi szektor szakembereitől csak a pedagógusok fele kap, de igényelné. Célirányos továbbképzésen $67,7 \%$ nem vett részt, pedig fontosnak tartaná. A pedagógusok másik része sem speciálisan gyermekvédelmi képzésen vett részt, bár a tudásanyagot hasznosíthatónak tartja e tanulókkal folytatott oktató-nevelő tevékenysége során.

A válaszadók 66,5\%-a arról számolt be, hogy folyamatos, rendszeres kapcsolata van gyermekvédelmi szakemberekkel - általában ez nevelőszülőt jelen -, és e kapcsolatot mindkét részről kezdeményezik, de inkább a pedagógusok a kezdeményezők. A kapcsolattartás módja általában szóbeli megkeresés, de általános az írásbeli is. Gyakoriságát tekintve eseti, néhány hetente és havonkénti. A kapcsolat minőségét ötös skálán a választ adó pedagógusok nagy része négyesre, hármasra értékelte.

A pedagógusok a gyermekvédelemben élő tanulók iskolai teljesítményének javulását leginkább befogadó szemlélettel, a tanulók alapos megismerésére törekvéssel, valamint pozitív tanár-diák kapcsolat kialakításával segítik. Az új tanítási módszerek megismerésére, célirányos továbbképzéseken való részvételre és a szakirodalom rendszeres tanulmányozására fordítanak a legkevesebb energiát.

A megkérdezett tanárok, tanítók 53,1\%-a gyermekvédelmi szakellátott tanítványaik rezilienciáját - megbirkózó képességét - ötös skálán hármas erősségúre értékelik. E tanulókat véleményük szerint a jó tanulmányi eredmény eléréséhez leginkább a nevelőcsalád, a gyermekotthon, a tanulási motiváció, az akarat, a kitartás és a tưrőképesség segíti hozzá. Gátolja a jó tanulmányi eredmény elérését esetükben az alacsony szülői iskolázottság, a tanulási, magatartási problémák, valamint a problémás tanár-diák viszony.

A választ adó pedagógusok a professzionális pedagógus jellemzők közül önmagukat esélyteremtésre törekvéssel, magas érzelmi intelligenciával, nagyfokú szakmai együttműködéssel jellemezték. Kevésbé érzik önmagukra érvényesnek az önképzésre törekvést és az inkluzív szemlélet gyakorlatát.

Volt tanítványaik jellemzően szakiskolában (2016/17-es tanévtől szakközépiskola) tanulnak tovább. Az egésznapos iskolát a megkérdezett kollégák 55,8\%-a véli hasznosnak a gyermekvédelmi szakellátott tanulók esetében. Úgy vélik, hogy a vér szerinti családban élő hátrányos helyzetú tanulók esetében is hasonló problémákkal küzdenek azok iskolai pályafutása során, mint az onnan kiemelt tanulókkal, bár más az élethelyzetük. 
Az esetleges siker kulcsaként a pozitív tanár-diák kapcsolatot, a bizalom, türelem, szeretet létét és a nevelő család pozitív hozzáállását jelölték meg. A kudarc okaként szintén a nevelő család hozzáállását, a magatartási problémát, az érzelmi biztonság hiányát és a negatív mintakövetést nevezték meg.

\section{Eredmények - gyermekvédelmi dolgozók}

A vizsgált témára más oldalról a gyermekvédelmi szakemberekkel készült interjúk és fókuszcsoportos beszélgetések derítettek fényt. Az interjúalanyok és a fókuszcsoport résztvevői között volt gyermekotthon-vezető, nevelőszülői tanácsadó, gyám és nevelőszülő is. Fontos megállapításuk, hogy a gyermekvédelemben élő tanulókkal iskolai oktatási-nevelési keretek között dolgozó pedagógusok szemlélete nem változik az új oktatási trendeknek megfelelően, hiányoznak a közös fórumok, továbbképzések, esetmegbeszélések. Inkább csak információáramlást jelent a közös kapcsolat, nem érdemi megoldásokat.

Rávilágítottak arra a tényre is, hogy e tanulókkal való egyéni bánásmód nagyon fontos, hiszen szinte kivétel nélkül érzelmileg sérültek. Véleményük szerint a pedagógusok személyiségétól, felkészültségétől függ, hogy a gyermekvédelemben élő tanulókkal hogyan tudnak együtt dolgozni. Jónak tartanának szektorközi fórumokat, szakmai megbeszéléseket, közös rendezésú konferenciákat, amelyeken olyan ismereteket szerezhetnének a pedagógusok, melyek hasznosak lehetnek a gyermekvédelmi szakellátásban élő tanulókkal folytatott oktatónevelő munka során.

A megkérdezett nevelőszülők csoportja kor és iskolai végzettség, lakóhely, valamint nevelőszülői tevékenység területén szerzett szakmai tapasztalat alapján heterogén. Véleményük szerint jó a kapcsolat az iskola és a nevelőcsalád között, az egyes intézmények tájékoztatási szokásait megfelelőnek tartják. Gyermekeik tanulmányi eredményével is elégedettek, úgy vélik, minden segítséget megkapnak gyengébb eredmény esetén. A gyermekeiket tanító tanítók és tanárok segítőkészségét, toleranciáját megfelelő szintűnek ítélik meg. Elmondásuk szerint a magatartási problémákat azonban nem minden pedagógus kezeli jól. Előfordul néha hátrányos megkülönböztetés is, melyet több eset említésével igazoltak.

\section{Összegző megállapítások}

A bemutatott vizsgálat előfeltevése volt, hogy Bács-Kiskun megyében a gyermekvédelemben felnövekvő tanulók iskolai esélyteremtésében és iskolai eredményességében tematizálható problémák vannak. Az eredmények rámutattak néhány, a témával kapcsolatos kulcsproblémára. Láthatóan a pedagógusok nem felkészültek a gyermekvédelemben élő tanulókkal való egyéni bánásmódra, valamint e tanulók iskolai eredményességének növelésére. A választ adó pedagógusok közel $80 \%$-a szerint nehézséget jelent e tanulók oktatása-nevelése. $E$ nehézségek elsősorban magatartási, tanulmányi, értékorientációs, illetve motivációs problémaként definiálhatók. A kollégák $87 \%$-a sem a pedagógusképzés, sem a továbbképzések során nem kapott célirányos képzést e nehézségek megoldására.

A kutatás további hipotézise volt, hogy a pedagógusok nem vesznek részt olyan továbbképzéseken, melyek fókuszálnak a gyermekvédelemben felnövő tanulók sajátosságaira, érdekükben sikeresen alkalmazható pedagógiai módszerekre. A megkérdezett pedagógusok arról számoltak be, hogy bár több továbbképzésen, másoddiplomás képzésen részt vettek, mégsem szereztek olyan tudást, mely speciálisan e tanulókra vonatkoznak. Az Oktatási Hivatal gyermek- és ifúságvédelmi szakvizsgára felkészítő képzést ugyan kínál, de itt a képzési idő években mérhető és nagyobb anyagi vonzata is van. 
A vizsgálat előtti feltételezés, miszerint problémát okoz, hogy Bács-Kiskun megyében nincs rendszerszintű együttmúködés az oktatási és a szociális szektor között, valamint az iskola és a gyermekvédelmi rendszer dolgozóinak kapcsolata sem megfelelő, igazolódott. Nincs személyes, naprakész kapcsolat, párbeszéd, segítségnyújtás a gyermekvédelemben dolgozó szakemberek és a pedagógusok között. Probléma esetén az iskolák nem rendelkeznek külön cselekvési tervvel ezek kezelésére. A megkérdezett pedagógusok és nevelőszülók szerint inkább van kapcsolat és ez pozitív minőségú. A gyermekotthon vezetője és a nevelőszülői tanácsadó szerint azonban pedagógusfüggő, hogy hogyan kezelik a problémákat. Inkább nem értékelték jónak a tanárok, tanítók helytállását. A megkérdezett nevelők szerint iskolájuk speciálisan a gyermekvédelmi szakellátott tanulókra vonatkozó cselekvési tervvel nem rendelkezik, bár problémát okoz az oktatásuk-nevelésük. Nincs megfelelő mennyiségú és minőségű fórum, ahol a szakmai segítségnyújtás, a speciális ismeretek, információk átadása megtörténhet.

Feltételezés volt az is, hogy az általános pedagógusképzés során a kötelező kurzusok tananyaga nem tér ki külön a gyermekvédelemben élő tanulókkal kapcsolatos ismeretanyagra. Ez a pedagógusképző intézmények tanítóképző és tanárképző karára vonatkozóan igazolódott. Inkább csak választható tananyagként jelenik meg a gyermekvédelem, így a hallgató érdeklődési köre dönti el e tudástartalom elsajátítását.

Előfeltevésként jelent meg, hogy megtalálhatók olyan kidolgozott módszerek, projektek az iskolai gyakorlatokban, amelyeket speciálisan a gyermekvédelemben felnövő tanulók fejlesztésére, esélyteremtésére, tanulás segítésére alkalmaznak. Ez a feltevés csak részben igazolódott. A megkérdezett tanárok, tanítók önmagukat inkluzív szemléletúnek vallják, ezt támasztja alá a választ adó nevelőszülők véleménye is, azonban a tanácsadó, gyermekotthon vezető és egy nevelőszülő szerint ez inkább csak elméleti, gyakorlatban ezt csak részben tapasztalják. Az esélyteremtésre, tanulássegítésre csak egyéni megoldások vannak, ezekre a pedagógusoknak nincs egységes, deklarált válasza.

A bemutatott vizsgálat eredményei megerősítették, hogy a gyermekvédelmi szakellátásban összetett problémahalmazzal, traumával élő gyermekek esélyegyenlőségének biztosítása, méltányosságot érvényesítő támogatása, a velük való egyéni bánásmód alkalmazása, a tanulmányi teljesítményük emeléséhez szükséges eszközök és humánerőforrások felkutatása, felhasználása, az inkluzív szemlélet gyakorlati alkalmazása, a partneri együttmúködési háló megerősítése területein még bőven van teendő. 


\section{Szakirodalom}

1. Bárdossy, I. (2000). Esély(teremtés) és együttmúködés. Retrieved from http://epa.oszk.hu/00000/00035/00034/2000-01-ei-Bardossy-Eselyteremtes.html (2015. 02. 10.)

2. Bárdossy, I. (2006). A befogadó iskola és környezete. Új Pedagógiai Szemle, 2006, 56 (3), 35-45. Retrieved from http://epa.oszk.hu/00000/00035/00101/2006-03-ta-Bardossy-Befogado.html (2015. 02. 12.)

3. Bourdieu, P. (1978). A társadalmi egyenlötlenségek újratermelödése. Budapest: Gondolat Kiadó.

4. Fehérvári, A. (2015a). Lemorzsolódás és a korai iskolaelhagyás trendjei. Neveléstudomány, 3, 31-47.

5. Fehérvéri, A. (2015b). A hátrányos helyzetű tanulók oktatásának változása. In Fehérvári, A. \&Tomasz, G. (Ed.), Kudarcok és megoldások - Iskolai hátrányok, lemorzsolódás, problémakezelés (pp. 31-52). Budapest: Oktatáskutató és Fejlesztő Intézet.

6. Fülöpné, A. K. (2003). A nevelőszülőknél élő gyermekek tanulási és magatartási zavarainak kezelési lehetőségei, illetve nehézségei a szakellátásban. Kapocs, 2(6), 46-50.

7. Hart, D. \& Williams, A.(2014). A korporált szülői szerepvállalás gyakorlatban való múködése. In Rácz A. (Ed.), Gyermek- és iffúságvédelmi Tanulmányok (pp. 52-78). Budapest: Rubeus Egyesület. Retrieved from http://rubeus.hu/wpcontent/uploads/2014/05/CPnemzetkozi_2014_final.pdf. (2019. 06. 20.)

8. Híves, T. (2015). A hátrányos helyzet területi aspektusai. In Fehérvári, A. \& Tomasz, G. (Ed.), Kudarcok és megoldások - Iskolai hátrányok, lemorzsolódás, problémakezelés (pp. 17-34). Budapest: Oktatáskutató és Fejlesztő Intézet.

9. Kalocsainé, S. H. \& Varga, A. (2005). Az iskola mint társadalmi és oktatási idea. Educatio, 1, 204-208.

10. Kertesi, G. \& Kézdi, G. (2012). A roma és nem roma tanulók teszteredményei közti különbségekről és e különbségek okairól. Közgazdasági Szemle, 59 (7-8), 798-853.

11. Mayer, J.(2006). Az első, a második és az n-edik iskolai esély. Hátrányos helyzetú tanulók iskolai kudarcai és a kompenzáció lehetőségei. Új Pedagógiai Szemle, 2006, 56 (12), 37-54. Retrieved from http://epa.oszk.hu/00000/00035/00109/2006-12-3l-Mayer-Elso.html (2015. 02. 21.)

12. Mihály, O. (1999). Esélyegyenlőség és differenciálás. Új Pedagógiai Szemle, 1999, 1, 11-19. Retrieved from http://epa.oszk.hu/00000/00035/00023/1999-01-ko-Mihaly-Eselyegyenloseg.html (2015. 02. 06.)

13. Platthy, I. (1994). Állami gondozott gyermekek és fiatalok személyiségfejlesztése a képzőművészet eszközeivel. Fejlesztő Pedagógia, 1994, 5 (2-3), 42-52.

Retrieved from http://www.iearn.org.au/fp/art/stories/roma/honlap2/tan.htm\#11 (2015. 02. 13.)

14. Rácz, A. (2012). Gyermekvédelemben nevelkedettek helyzete a kutatások tükrében. In Rácz, A. (Ed.), Gyermek- és iffúságvédelmi Tanulmányok (pp. 13-35). Budapest: Rubeus Egyesület. Retrieved from http://rubeus.hu/wpcontent/uploads/2013/09/24428_gyermek_es_ifusagvedelmi_tanulmanyok_elso _kotet.pdf13-35 (2019. 06. 21.)

15. Réthyné, E. (1988). A tanítás-tanulási folyamat motivációs lehetőségeinek elemzése. Budapest: Akadémiai Kiadó.

16. Varga, A. (2008). A gyermekvédelmi gondoskodásban élők inklúziójának esélyei. Retrieved from http://www.ofi.hu/tudastar/varga-aranka (2015. 02. 16.)

17. Varga, A. (2012). Metszéspontok. Gyermekvédelem és iskola. Pécs: PTE BTK Oktatáskutató Központ.

18. Varga, A. (2015a). Esélyegyenlőség és inklúzió az iskolában. In Varga Aranka (Ed.), A nevelésszociológia alapjai (pp. 241-273). Pécs: PTE - WHSz

19. Varga, A. (2015b). Az inklúzió szemlélete és gyakorlata. Pécs: PTE - WHSz. 


\section{School Opportunities of Students in Child Protection}

In this paper I write about the chances of the children taken into a child abuse prevention at school. Growing up in this prevention and becoming adults these children and young people might be stucked into the lower part of society. Their social integratism is also doubtful because of the lack of the social discrimination, the valuable relation, the financial, cultural and social capital. The knowledge getting at school might be the key of their upwards. Well-organised educational system and well-trained teachers might give chance and help to get this knowledge, to become educated, trained. That is why I set out to search the school difficulties and specific problems of these teachers working with these protected children in elementary schools in BácsKiskun County. The strategy of my research consist of the characteristics of both inductive and deductive strategies. I chose the method of document analysis, oral interview and written questioning. In Bács-Kiskun County, there are issues that can be themed in the school setting and school success of pupils in child protection. Teachers are not prepared enough for individual treatment of pupils living in child protection, and to improve their school performance. Most of the teachers do not participate in further training that focuses specifically on teaching methods that can be successfully applied to pupils in child protection. In general teacher education, the curriculum of compulsory courses does not specifically address the knowledge of pupils living in child protection.

Keywords: child protection, chance, educators 